\title{
UJ PATOGENISITAS DAN VIRULENSI Aeromonas hydrophila Stanier PADA IKAN NILA (Oreochromis niloticus Lin.) MELALUI POSTULAT KOCH
}

\author{
Wibowo Mangunwardoyo"), Ratih Ismayasari"*), dan Etty Riani ${ }^{* * * x}$ \\ *) Departemen Biologi, Fakultas Matematika dan IImu Alam \\ Universitas Indonesia, Depok 16424 \\ E-mail: w_mangunwardoyo@hotmail.com \\ **) Stasiun Karantina Ikan Klas I Tanjung Priok \\ Jl. Enggano Raya 16, Pelabuhan Tanjung Priok, Jakarta Utara \\ ***) Fakultas Perikanan dan Ilmu Kelautan, Institut Pertanian Bogor \\ Jl. Rasamala, Kampus IPB, Darmaga, Bogor, 16680
}

(Naskah diterima: 14 Agustus 2009; Disetujui publikasi: 26 April 2010)

\begin{abstract}
ABSTRAK
Bakteri Aeromonas hydrophila bersifat patogen mengakibatkan kematian sebanyak $50 \%$ pada ikan nila di keramba jaring apung. Penelitian ini bertujuan untuk meneliti patogenisitas dan virulensi dari dua enzim dan satu toksin haemolisin yang dihasilkan oleh A. hydrophila pada ikan nila yang sehat. Analisis LC-50 menggunakan metode Dragsted Bahrens menghasilkan nilai $4,9 \times 10^{6} \mathrm{cfu} / \mathrm{mL}$. Virulensi A. hydrophila diuji menggunakan metode Postulat Koch pada ikan nila sehat menyebabkan tubuh menjadi kemerah-merahan, perdarahan pada permukaan tubuh dan luka borok yang akhirnya menyebabkan kematian.
\end{abstract}

KATA KUNCl: Aeromonas hydrophila, LC-50, Postulat Koch, tubuh kemerahmerahan, perdarahan dan luka borok

ABSTRACT: Pathogenicity and virulency of Aeromonas hydrophila stainer on nila fish (Oreochromis niloticus Lin.) using koch postulate. By: Wibowo Mangunwardoyo, Ratih Ismayasari, and Etty Riani

Aeromonas hydrophila is a highly pathogenic bacterium which caused more than $50 \%$ nila's mortality at the pond culture. The purpose of the research was study on the virulence and pathological effect of two A. hydrophila's enzymes and one toxin haemolycin on a healthy's nila fish. Lethal Concentration 50 with injection of A. hydrophila on nila was used as preliminary test to determine bacterial density that caused 50\% nila's mortality. The $L C_{50}$ was $4,9 \times 10^{6} \mathrm{cfu} / \mathrm{mL}$ determined by Dragsted Bahrens methods. The A. hydrophila virulence test with The Postulat Koch had been effects on healthy's nila, with clinical sign were reddening, haemorrhagic all over the body surface, and ulcer which caused mortality.

KEYWORDS: Aeromonas hydrophila, LC-50, Koch Postulate, reddening, haemorrhagic, ulcer 


\section{PENDAHULUAN}

Keberhasilan budidaya ikan nila terkait dengan pemeliharaan kesehatan lingkungan dan penyakit ikan yang disebabkan oleh bakteri. Salah satu bakteri yang umum dijumpai di dalam ekosistem perairan dan berperan sebagai microbial flora bagi hewan-hewan air pada kondisi lingkungan stabil, adalah Aeromonas hydrophila. Bakteri tersebut dapat menjadi patogen pada ikan nila pada kualitas air yang buruk. Selain itu, $A$. hydrophila juga memiliki kemampuan osmoregulasi cukup tinggi, karena dapat hidup di lingkungan perairan tawar, perairan payau, dan laut yang memiliki kadar garam tinggi dengan penyebaran melalui air, kotoran burung, saluran pencernaan hewan darat, amfibi, dan reptilia (Swann \& White, 1991; Cipriano, 2001).

Menurut Noga (2000), bakteri A. hydrophila dapat menginfeksi banyak jenis ikan air tawar seperti Catfish, Cyprinidae, Cichlidae, Rainbow trout, Salmonidae, katak, siput, dan udang air. Kemampuan A. hydrophila dalam melakukan infeksi pada ikan terkait dengan kemampuan bakteri dalam menghasilkan toksin. Menurut Chopra et al. (2000), A. hydrophila termasuk ke dalam kelompok bakteri patogen dengan virulensi yang tinggi. Tingkat virulensi bakteri tersebut ditentukan oleh kemampuan bakteri menghasilkan enzim dan toksin tertentu yang berperan dalam proses invasi dan infeksi. Sebagai faktor-faktor vilrulensi, kitinase, lesitinase, dan hemolisin yang dihasilkan oleh $A$. hydrophila, bekerja dengan mendegradasi jaringan dan menimbulkan luka serta pendarahan pada ikan inang (Del Coral et al., 1990).

Ikan-ikan yang terinfeksi oleh bakteri A. hydrophila pada umumnya mengalami pendarahan yang meluas pada permukaan kulit (Haemorrhagic septicemia), yang diikuti dengan timbulnya luka terbuka (ulcer) pada permukaan tubuh atau hingga ke dalam jaringan. Selain itu, pada beberapa jenis ikan lain sering ditemukan tanda klinis seperti sirip punggung dan sirip ekor rontok, serta pembengkakan pada perut dan berisi cairan (dropsy), yang diikuti dengan kematian (Popma \& Masser, 1999; Yuasa et al., 2003).

Jawetz et al. (1996) menyatakan bahwa untuk mengetahui penyebab utama suatu penyakit perlu dilakukan pengujian Postulat Koch. Ikan uji harus menunjukkan gejala klinis yang sama, dengan ikan yang sakit. Tingkat virulensi bakteri, menurut Lallier et al. (1981); Komisi Pestisida (1983), dapat diketahui dengan mencari Lethal Concentration $\left(\mathrm{LC}_{50}\right)$, sebagai uji pendahuluan untuk mengetahui kepadatan bakteri tertinggi yang dapat mematikan $50 \%$ ikan uji dalam waktu 96 jam. Hasil uji LC $_{50}$, selanjutnya digunakan dalam pengujian utama yaitu uji virulensi $A$. hydrophila pada ikan nila menggunakan tiga tingkat kepadatan bakteri yang berbeda.

Patogensitas dan tingginya virulensi $A$. hydrophila pada ikan nila ditentukan oleh faktor-faktor virulensi yang dihasilkan oleh bakteri. Penelitian yang dilakukan bertujuan untuk mengetahui patogenisitas dan virulensi bakteri tersebut pada ikan nila dan penentuan Lethal Concentration $\left(\mathrm{LC}_{50}\right)$.

\section{BAHAN DAN METODE}

\section{Ikan Sampel}

Ikan sampel adalah ikan nila (Oreochromis niloticus Lin) berasal dari kolam pembesaran ikan Sekolah Tinggi Penyuluh Perikanan Cikaret, Bogor sebanyak 250 ekor dengan panjang 7-10 cm dan bobot badan 20-30 g.

\section{Persiapan peralatan uji}

Peralatan instalasi yang akan digunakan pada pengujian virulensi: $A$. hydrophila pada ikan nila adalah akuarium $30 \mathrm{~cm} \times 20 \mathrm{~cm} \times 20$ $\mathrm{cm}$ dan aerator. Akuarium dan selang aerasi sebelum digunakan terlebih dahulu didesinfeksi di dalam larutan Kalium permanganat $\left(\mathrm{KMnO}_{4}\right)$ 2,5 mg/L selama 24 jam (Yuasa et al., 2003). Ikan sampel diaklimatisasi dalam akuarium beraerasi selama 7 hari.

Peningkatan virulensi $A$. hydrophila dengan tujuan meningkatkan kembali patogenisitas dan virulensi bakteri dilakukan dengan menginfeksikan $A$. hydrophila pada ikan uji dengan teknik penyuntikan. Perlakuan tersebut dilakukan berdasarkan asumsi bahwa bakteri akan mengalami penurunan kemampuan dan aktivitas metabolisme setelah melewati waktu 24 jam pada fase stasioner, sesuai dengan perkembangan kurva pertumbuhan bakteri (Moat et al., 2002). Suspensi bakteri disiapkan dengan memindahkan koloni $A$. hydrophila ke dalam Tripton Soya Broth (TSB) $10 \mathrm{~mL}$, kemudian diaduk dengan menggunakan minimikser sampai homogen. Suspensi sebanyak $0,1 \mathrm{~mL}$ disuntikkan secara intraperitoneal dengan 
jarum suntik $(1 \mathrm{~mL})$ pada lima ekor ikan nila yang sebelumnya diinaktifkan dengan cara dicelupkan di dalam air suhu $25^{\circ} \mathrm{C}$ selama 30 detik. Ikan nila yang telah disuntik selanjutnya dimasukkan ke dalam $10 \mathrm{~L}$ air di dalam akuarium $30 \mathrm{~cm} \times 20 \mathrm{~cm} \times 20 \mathrm{~cm}$, dan dibiarkan selama 48 jam atau sampai tampak gejala klinis pada ikan. Isolasi bakteri kembali dilakukan dari organ ginjal dan daerah luka pada ikan yang mengalami hemoragik menggunakan BHIA. Setelah 24 jam masa inkubasi di dalam suhu $30^{\circ} \mathrm{C}$, satu koloni bakteri dominan diinokulasikan kembali ke dalam media BHIA dan diinkubasi kembali pada suhu yang sama. Re-identifikasi bakteri dilakukan setelah bakteri dimurnikan dan mencapai fase eksponensial (24 jam), dengan pewarnaan Gram dan pengujian karakter biokimia. Untuk mengetahui kemampuan hemolisis, bakteri tersebut diinokulasikan ke permukaan media agar darah, dan diamati zona lisis yang terjadi.

\section{Lethal Consentration (LC)}

Uji LC $_{50}$ dilakukan untuk mengetahui kepadatan konsentrasi bakteri yang dapat mematikan 50\% ikan uji. Lima kepadatan bakteri $A$. hydrophila digunakan untuk

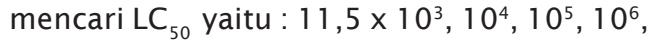
dan $10^{7} \mathrm{cfu} / \mathrm{mL}$. Perhitungan koloni bakteri dilakukan menggunakan Plate Count Agar (PCA), dengan teknik perhitungan Total Plate Count (TPC) (Maturin \& Peeler, 1998). Akuarium yang digunakan sebanyak 18 buah, dibagi 6 kelompok. Setiap kelompok terdiri atas tiga akuarium yang masing-masing berisi 8 ekor ikan nila. Kelompok I diberikan perlakuan penyuntikan $A$. hydrophila melalui intraperitoneal dengan kepadatan bakteri 11,5 × $10^{3}$ $\mathrm{cfu} / \mathrm{mL}$, kelompok II : 11,5 x 104 $\mathrm{cfu} / \mathrm{mL}$, kelompok III : $11,5 \times 10^{5} \mathrm{cfu} / \mathrm{mL}$, kelompok IV: $11,5 \times 10^{6} \mathrm{cfu} / \mathrm{mL}$, dan kelompok $\mathrm{V}: 11,5 \times$ $10^{7} \mathrm{cfu} / \mathrm{mL}$. Kelompok VI adalah ikan kontrol, juga diberikan perlakuan dengan penyuntikan larutan Phosphate Buffer Saline (PBS). Volume suspensi bakteri yang disuntikan pada setiap ikan adalah 0,1 mL. Rancangan percobaan yang digunakan adalah rancangan acak lengkap dengan tiga kali pengulangan perlakuan (Sudjana, 1988). Perubahan tingkah laku, gejala klinis dan kematian ikan diamati setiap 12 jam selama empat hari. Pengukuran kualitas air dilakukan dua kali sehari, yaitu pukul 07.00 dan 18.00 WIB. Nilai LC $_{50}$ ditentukan dengan metode Dragsted Behrens (Hubbert, 1980).

\section{Uji virulensi $A$. hydrophila pada ikan nila secara in vivo dengan Postulat Koch}

Hasil perhitungan $\mathrm{LC}_{50}$ digunakan untuk uji utama yaitu uji virulensi $A$. hydrophila pada ikan nila. Pada uji virulensi setiap ekor ikan nila uji disuntikkan A. hydrophila sebanyak 0,1 $\mathrm{mL}$ melalui intraperitoneal menggunakan tiga kepadatan bakteri bertingkat yaitu 106, 10 dan $10^{8} \mathrm{cfu} / \mathrm{mL}$. Metode pengujian dan pengukuran kualitas air dilakukan sama seperti pada uji $\mathrm{LC}_{50}$. Perubahan tingkah laku, kelainan patologi, gejala klinis yang timbul dan tingkat kematian diamati setiap 12 jam selama 4 hari.

\section{HASIL DAN BAHASAN}

\section{Hasil}

Peningkatan virulensi, isolasi dan identifikasi Aeromonas hydrophila

Peningkatan virulensi $A$. hydrophila dilakukan dengan tujuan mengembalikan patogenitas bakteri tersebut, sehingga memiliki tingkat virulensi yang tinggi. Sebelum penyuntikan dilakukan ikan nila tidak menunjukkan gejala hiperaemia, tetapi setelah Infeksi bakteri 48 jam, timbul gejala klinis pada permukaan tubuh seperti warna bagian perut menjadi putih, hemoragik meluas pada permukaan tubuh, pangkal sirip ekor dan operkulum (Gambar 1), serta perubahan patologi internal seperti pembengkakkan organ hati, limpa, dan pendarahan pada lambung (Gambar 2). Identifikasi bakteri yang diisolasi dari organ ginjal dan luka menunjukkan bakteri tersebut adalah $A$. hydrophila.

\section{Pengujian Lethal Concentration (LC) 50}

Perhitungan hasil $\mathrm{LC}_{50}$ menunjukkan bahwa persentase kematian ikan nila setelah penyuntikan dengan kepadatan bakteri yang berbeda mengalami peningkatan kematian sejalan dengan meningkatnya kepadatan bakteri (Tabel 1). Hasil analisis data dengan metode Dragsted Behrens menghasilkan $4,9 \times 10^{6} \mathrm{cfu} / \mathrm{mL}$ sebagai kepadatan bakteri A. hydrophila yang dapat mematikan $50 \%$ ikan uji.

Tabel 1 memperlihatkan persentase kematian ikan nila meningkat dengan bertambahnya kepadatan bakteri. Makin tinggi 

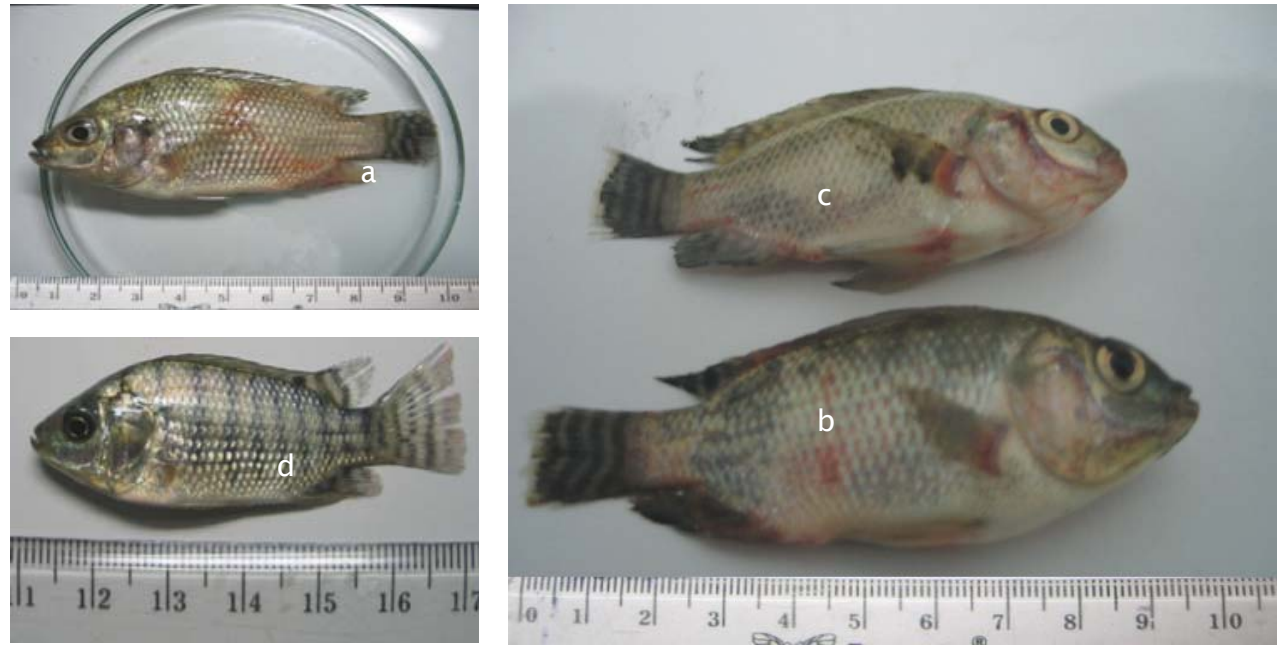

Keterangan: a. haemorrhagic septicamia, b. luka, c. hemoragik lokal pada pangkal sirip dada, d. ikan sehat

Legends: a. haemorrhagic septicaemia, b. ulcer, $c$. haemorrhagic on the base pectoralis fin, $d$. healty fish

Gambar 1. Gejala klinis yang timbul pada perlakuan peningkatkan virulensi $A$. hydrophila

Figure 1. Clinical sign appeared on the treatment increasing virulency of A. hydrophila

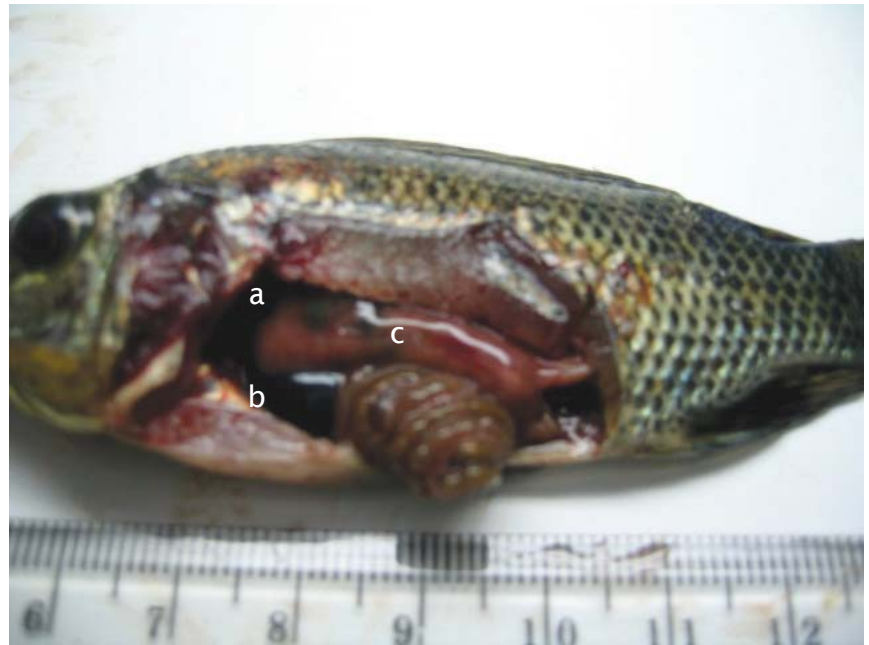

Keterangan: a. pembengkakan hati, b. pembengkakan limpa, c. pendarahan pada lambung

Legends: $a \& b$ heart and lymph sweeling, c. bleeding on the gastric

Gambar 2. Kelainan patologi organ hati, limpa, dan lambung pada perlakuan peningkatkan virulensi $A$. hydrophila

Figure 2. Pathological changes on heart, lymph, and gastric on the treatment of increasing virulence of $\boldsymbol{A}$. hydrophila 
Tabel 1. Persentase tingkat kematian ikan nila setelah infeksi $A$. hydrophila (96 jam) pada uji $\mathrm{LC}_{50}$

Table 1. Presentage of mortality nile tilapia after infected by A. hydrophila (96 hours) on of $L C_{50}$ test

\begin{tabular}{ccccc}
\hline $\begin{array}{c}\text { Kepadatan bakt eri } \\
\text { Bacteria density } \\
\text { (cfu/mL) }\end{array}$ & \multicolumn{3}{c}{ Ulangan (Repeated) } & $\begin{array}{c}\text { Rerata persentase kematian } \\
\text { Average of mortality } \\
\text { presentage (\%) }\end{array}$ \\
\cline { 2 - 4 } $10^{3}$ & I & II & III & 16.67 \\
$10^{4}$ & 1 & 1 & 2 & 20.83 \\
$10^{5}$ & 0 & 3 & 2 & 41.67 \\
$10^{6}$ & 4 & 4 & 2 & 45.83 \\
$10^{7}$ & 4 & 4 & 3 & 66.67 \\
\hline
\end{tabular}

kepadatan bakteri yang diinfeksikan pada ikan, makin tinggi pula tingkat kematian ikan. Perhitungan dengan metode Dragsted Behrens menetapkan kepadatan A. hydrophila $4,9 \times 10^{6} \mathrm{cfu} / \mathrm{mL}$ sebagai $\mathrm{LC}_{50}$.

Uji virulensi Aeromonas hydrophila pada ikan nila secara in vivo melalui Postulat Koch

Hasil uji virulensi (Tabel 2), memperlihatkan terjadinya peningkatan terhadap persentase kematian ikan, seperti pada uji LC $_{50}$. Ikan uji mengalami perubahan patologi eksternal dan internal selama perlakuan. Ikan nila dengan perlakuan infeksi bakteri $10^{6} \mathrm{cfu} / \mathrm{mL}$ sebagian besar memperlihatkan perubahan patologi seperti tubuh menjadi gelap, lemah, tidak responsif, dan terdapat pendarahan lokal. Organ internal ikan nila memperlihatkan terjadi pembengkakkan pada organ hati dan limpa, serta pendarahan pada lambung (Gambar 3). Tanda klinis makin jelas pada infeksi bakteri $10^{8} \mathrm{cfu} / \mathrm{mL}$, seperti adanya ulcer yang merupakan luka borok terbuka disertai pendarahan di sekeliling luka (Gambar 4).
Data pada Tabel 2, menunjukkan terdapat perbedaan persentase kematian yang cukup tinggi antar setiap perlakuan. Persentase kematian tertinggi 91,66\% terjadi pada perlakuan infeksi dengan kepadatan bakteri $10^{8} \mathrm{cfu} / \mathrm{mL}$. Persentase kematian terendah sebesar 54,16\% terjadi pada perlakuan infeksi dengan kepadatan $10^{6} \mathrm{cfu} / \mathrm{mL}$, yaitu kematian yang terjadi lebih dari $50 \%$ populasi ikan. Hasil pengukuran parameter kualitas air meliputi suhu, $\mathrm{pH}, \mathrm{DO}$, dan $\mathrm{CO}_{2}$ serta $\mathrm{NH}_{3}$ selama perlakuan memperlihatkan lima parameter tersebut masíh dalam kisaran batas normal (Tabel 3).

Pengamatan terhadap perubahan patologi eksternal dan internal dilakukan terhadap setiap ekor ikan yang mengalami kematian. Gambar 3. memperlihatkan terjadinya pembengkakkan pada organ hati dan limpa serta pendarahan pada usus ikan nila yang telah diberi perlakuan infeksi dengan kepadatan bakteri $10^{6} \mathrm{cfu} / \mathrm{mL}$ pada uji virulensi. Perubahan patologi pada organ hati dan limpa telah terjadi pada hari pertama setelah penyuntikan dan semakin nyata setelah hari keempat.

Tabel 2. Persentase tingkat kematian ikan nila setelah uji virulensi (96 jam)

Table 2. Presentage level of mortality nile tilapia after virulence test (96 hours)

\begin{tabular}{ccccc}
\hline $\begin{array}{c}\text { Kepadatan bakt eri } \\
\text { Bacteria density } \\
\text { (cfu/mL) }\end{array}$ & \multicolumn{3}{c}{ Ulangan (Repeated) } & $\begin{array}{c}\text { Persentase kematian } \\
\text { Mortality presentage } \\
\text { (\%) }\end{array}$ \\
\hline $10^{6}$ & I & II & III & 54.16 \\
$10^{7}$ & 4 & 4 & 5 & 66.67 \\
$10^{8}$ & 6 & 5 & 5 & 91.66 \\
\hline
\end{tabular}




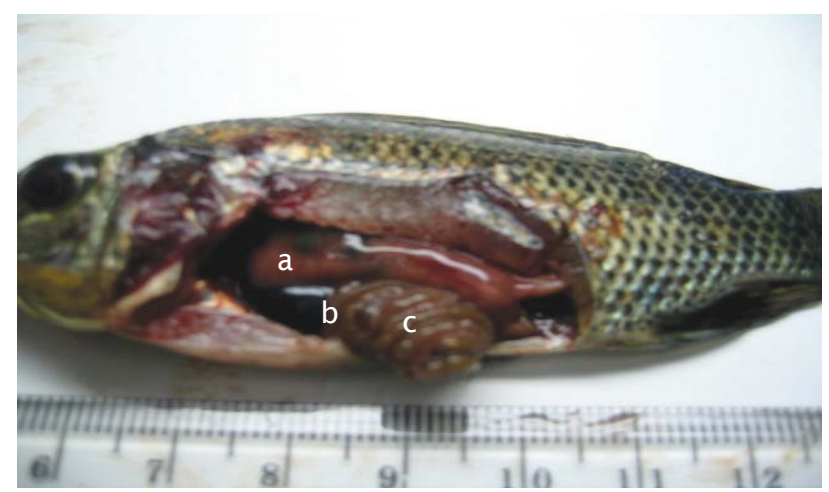

Keterangan: a \& b hati dan limpa membengkak, c. pendarahan pada lambung

Legends: $a \& b$ heart and lymph sweeling, c. bleeding on the gastric

Gambar 3. Perubahan patologi organ internal ikan nila hari ke 4 pada uji virulensi $A$. hydrophila $10^{6} \mathrm{cfu} / \mathrm{mL}$

Figure 3. Pathological changes of internal organ of nile tilapia at the 4 days after treated with $A$. hydrophila $10^{6} \mathrm{cfu} / \mathrm{mL}$

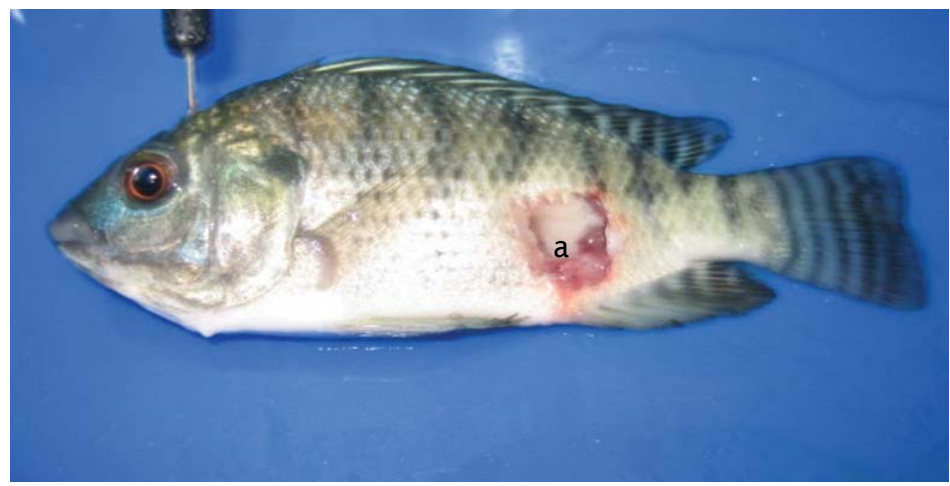

Keterangan: a. ulcer disertai pendarahan di sekitar luka Legends: a. ulcer and bleeding around the scar

Gambar 4. Ulcer pada tubuh ikan nila pada uji virulensi $A$. hydrophila $10^{8} \mathrm{cfu} / \mathrm{mL}$

Figure 4. Ulcer on the body surface of nile tilapia on virulency test of A. hydrophila $10^{8} \mathrm{cfu} / \mathrm{mL}$

Gambar 4 memperlihatkan ikan nila yang telah diinfeksi dengan kepadatan bakteri $10^{8}$ $\mathrm{cfu} / \mathrm{mL}$, mengalami luka terbuka atau ulcer di daerah lokasi penyuntikan yang disertai pendarahan. Tubuh ikan semakin pucat, dan ikan menunjukkan tanda moribund pada hari keempat sebelum ikan mati. Hasil nekropsi memperlihatkan terjadinya infeksi pada hati dan limpa.

\section{BAHASAN}

Peningkatan Virulensi, Isolasi, dan Identifikasi Aeromonas hydrophila

Peningkatan virulensi $A$. hydrophila dilakukan dengan dua kali ulangan bertujuan meningkatkan kembali patogenisitas dan virulensi bakteri, sehingga infeksi $A$. 
Tabel 3. Rerata hasil pengukuran kualitas air pemeliharaan pada uji virulensi A. hydrophila (96 jam)

Table 3. The average of measurement water quality on virulence test $\boldsymbol{A}$. hydrophila (96 hours)

\begin{tabular}{cccccc}
\hline \multicolumn{6}{c}{ Kont rol (Control) } \\
\hline $\begin{array}{c}\text { Hari } \\
\text { Days }\end{array}$ & $\begin{array}{c}\text { Suhu } \\
\text { Temperature }\left({ }^{\circ} \mathrm{C}\right)\end{array}$ & $\mathbf{p H}$ & $\begin{array}{c}\mathrm{CO}_{2} \\
(\mathrm{mg} / \mathrm{L})\end{array}$ & $\begin{array}{c}\mathrm{DO} \\
(\mathrm{mg} / \mathrm{L})\end{array}$ & $\begin{array}{c}\mathrm{NH}_{3} \\
(\mathrm{mg} / \mathrm{L})\end{array}$ \\
\hline 1 & 27 & $7.0-7.1$ & $4.0-5.0$ & $5.0-6.0$ & 0.5 \\
2 & 27 & $7.0-7.2$ & $5.0-5.5$ & $5.0-6.0$ & 1.0 \\
3 & 27 & $7.1-7.2$ & $5.5-6.0$ & $6.0-7.0$ & 1.0 \\
4 & 27 & $7.1-7.2$ & $5.5-7.0$ & $6.0-7.0$ & 1.0 \\
\hline \multicolumn{5}{c}{ Perlakuan (Treatment) } \\
\hline 1 & $26-27$ & $7.0-7.2$ & $4.0-5.0$ & $5.0-6.0$ & 0.5 \\
3 & 27 & $7.1-7.2$ & $5.0-5.5$ & $5.0-6.0$ & 1.0 \\
4 & 27 & $7.1-7.3$ & $5.5-6.0$ & $5.5-7.0$ & 1.0 \\
\hline
\end{tabular}

hydrophila pada ikan uji nila menjadi optimal. Isolasi dan identifikasi bakteri yang diambil dari ginjal dan luka menghasilkan bakteri dengan warna dan bentuk koloni, serta morfologi bakteri yang sama dengan karakter $A$. hydrophila. Identifikasi biokimia menunjukkan bakteri tersebut $A$. hydrophila.

Patogenisitas bakteri perlu ditingkatkan karena metabolisme bakteri dalam kultur in vitro dapat menurun setelah periode waktu tertentu. Menurut Moat et al. (2002), rerata bakteri mencapai pertumbuhan optimal pada fase eksponensial, yaitu pada jam ke-4-ke-12. Bakteri selanjutnya akan mengalami fase stasioner pada masa inkubasi sampai dengan $48 \mathrm{jam}$. Pada fase tersebut persentase antara bakteri yang hidup dan yang mati adalah sama. Bakteri akan mengalami fase kematian setelah melewati fase 24 jam. Kondisi tersebut terkait dengan ketersediaan nutrisi dan lingkungan yang tepat untuk kehidupan bakteri tersebut.

Selama masa pertumbuhan A. hydrophila yang dikultur di dalam media akan mengeluarkan metabolit primer maupun sekunder yang dapat menurunkan kualitas nutrisi di dalam media. Nutrisi yang tersedia di dalam media kultur sangat terbatas dan akan habis pada periode waktu tertentu. Kondisi tersebut dapat memengaruhi aktivitas dan patogenisitas bakteri (Maturin \& Peller, 1998).
Oleh karena itu, untuk meningkatkan kembali patogenisitas $A$. hydrophila yang telah 30 hari berada dalam kondisi inaktif, bakteri kembali disuntikkan ke dalam tubuh ikan nila, agar bakteri dapat kembali memproduksi senyawa yang bersifat toksin pada lingkungan yang tepat.

Isolat $A$. hydrophila yang digunakan dalam uji $\mathrm{LC}_{50}$ dan uji virulensi adalah bakteri yang telah berada di dalam media Brain Heart Infusion Agar (BHIA) dan sebelumnya telah digunakan dalam pengujian in vitro (enzim dan toksin ekstraselular). Isolat bakteri tersebut telah disimpan di dalam lemari pendingin dalam kondisi inaktif pada suhu $4^{\circ} \mathrm{C}$ selama 30 hari. A. hydrophila termasuk ke dalam bakteri mesofilik, yaitu hidup pada suhu optimum $20^{\circ} \mathrm{C}-40^{\circ} \mathrm{C}$. Menurut Moat et al. (2002), suhu rendah di dalam lemari pendingin dapat menyebabkan aktivitas enzim pada bakteri menurun bahkan hilang, sehingga mempengaruhi metabolisme dan patogenisitas bakteri tersebut. Kondisi suhu di luar batas optimum menyebabkan terjadinya lubang pada membran sel, diikuti dengan dikeluarkannya senyawa yang bersifat toksin, seperti superoxida yang toksik bagi bakteri itu sendiri. Ikan digunakan sebagai media uji virulensi, sebab ikan nila merupakan salah satu inang $A$. hydrophila dan di dalam tubuh ikan tersebut bakteri mendapatkan lingkungan dengan suhu, 
$\mathrm{pH}$, dan nutrisi yang cukup untuk hidup dan memperbanyak diri (Robert, 1993; Eissa et al., 1994).

Kembalinya patogenisitas dan virulensi bakteri dibuktikan dengan terjadi hiperaemia pada permukaan tubuh, hemoragik lokal pada pangkal sirip dan operkulum sesuai dengan gejala klinis yang ditimbulkan oleh infeksi $A$. hydrophila dan reaksi hemolisis pada agar darah (Santos, 1999; Filler et al., 2000). Luka dan hemoragik yang terjadi pada tubuh ikan diduga disebabkan oleh toksin ekstraselular yang bekerja bersinergi merusak jaringan pada tubuh ikan. Hemolisin yang dihasilkan oleh bakteri tersebut bekerja memecah dan melisiskan sel-sel darah merah. Hal tersebut terlihat dengan adanya luka dan pendarahan pada tubuh ikan nila. Pengujian pada media agar darah memperlihatkan terjadinya zona bening yang merupakan aktivitas $\beta$-hemolisis di sekeliling koloni, yang menunjukkan terjadinya proses lisis secara sempurna oleh A. hydrophila (Chopra et al., 2000).

\section{Uji Lethal Concentration $\left(\mathrm{LC}_{50}\right)$}

Pengujian $\mathrm{LC}_{50}$, dilakukan untuk mendapatkan kepadatan bakteri (cfu/mL) yang mampu mematikan $50 \%$ populasi ikan nila. Perhitungan dengan metode Dragsted Behreins menghasilkan $4,9 \times 10^{6} \mathrm{cfu} / \mathrm{mL}$ sebagai $\mathrm{LC}_{50}$. Terjadinya kematian pada ikan nila yang terinfeksi $A$. hydrophila membuktikan bahwa bakteri tersebut bersifat patogen dan sangat virulen pada ikan. Menurut Jawetz et al. (1996), bakteri termasuk mikroorganisme patogen apabila memiliki kemampuan untuk melakukan transmisi, perlekatan dengan sel inang, invasi sel dan jaringan inang, menyebabkan infeksi pada sel inang yang diikuti dengan kematian.

Hasil pengujian tersebut berbeda dengan pengujian yang dilakukan oleh Lallier et al. (1981) yaitu nilai LC $_{50}$ untuk $A$. hydrophila yang bersifat virulen pada ikan Rainbow trout adalah $10^{4} \mathrm{cfu} / \mathrm{mL}$. Menurut Lallier et al. (1981), A. hydrophila sangat virulensi apabila mampu mematikan $50 \%$ ikan uji pada kepadatan bakteri $10^{4} \mathrm{cfu} / \mathrm{mL}$, virulen sedang pada $10^{5} \mathrm{cfu} / \mathrm{mL}$ dan tidak virulen sama sekali pada $10^{6} \mathrm{cfu} /$ $\mathrm{mL}$. Pengujian yang telah dilakukan oleh Supriyadi (1990), menghasilkan $10^{5} \mathrm{cfu} / \mathrm{mL}$ sebagai $\mathrm{LC}_{50}$ pada ikan lele (Clarias batrachus). Perbedaan hasil pengujian dan perhitungan $\mathrm{LC}_{50}$ tersebut diduga akibat sumber asal bakteri dan ikan host yang digunakan sangat berbeda dan perbedaan waktu penelitian yang cukup lama. Menurut Swann \& White (1991), ikan nila secara morfologi memiliki perbedaan dengan ikan lele. Ikan nila memiliki sisik tubuh rapat dan memiliki kemampuan adaptasi lingkungan yang cukup tinggi, sedangkan ikan lele tidak memiliki sisik sehingga lebih rentan terhadap infeksi bakteri.

Keberadaan A. hydrophila di alam yang dengan mudah dapat ditemukan pada permukaan tubuh maupun organ dalam ikan nila sehat, sebab sifat bakteri yang oportunistik (Buckley \& Howard, 1999). Keadaan tersebut dan memberikan respons imun yang cukup besar bagi ikan nila, sehingga pada kepadatan bakteri di bawah $10^{6} \mathrm{cfu} / \mathrm{mL}$, belum dapat mematikan $50 \%$ populasi ikan nila.

A. hydrophila mampu mematikan 50\% populasi ikan lele pada $10^{5} \mathrm{cfu} / \mathrm{mL}$. Kepadatan bakteri tersebut lebih rendah dibandingkan dengan hasil uji pada ikan nila yaitu $10^{6} \mathrm{cfu} /$ $\mathrm{mL}$. Hal tersebut memperlihatkan adanya perbedaan tingkat virulensi bakteri pada ikan lele dan ikan nila. Ada 2 faktor yang berpengaruh yaitu: 1) ketahanan ikan yang berbeda dan 2) virulensi bakteri berbeda.

Terjadinya hal tersebut tersebut diduga akibat pertahanan tubuh ikan lele yang lemah. Untuk melindungi tubuh dari infeksi bakteri, lele akan mengeluarkan lendir terus-menerus sehingga mengakibatkan metabolisme tubuh meningkat, dan pemakaian energi lebih banyak. Akibatnya ikan menjadi cepat lemah dan mudah stres. Keadaan tersebut mempermudah bakteri untuk masuk dan menginfeksi dengan mengeluarkan toksin melalui tempat terbuka seperti insang, ekor atau sirip (Mims, 1987; Supriyadi, 1990).

\section{Uji Virulensi Aeromonas hydrophila pada Ikan Nila Secara in vivo melalui Postulat Koch}

Uji virulensi $A$. hydrophila melalui penyuntikan intraperitoneal menunjukkan bakteri tersebut sangat virulen pada ikan nila, sebab infeksi dengan kepadatan bakteri $10^{6}$ $\mathrm{cfu} / \mathrm{mL}$, ikan uji telah mengalami kematian sebesar $50 \%$ dalam waktu 96 jam Adapun gejala klinis berupa perubahan tingkah laku ikan menjadi lemah, tidak aktif dan tidak responsif, hemoragik lokal di pangkal sirip punggung, pangkal sirip ekor dan operkulum yang diikuti oleh kematian ikan. Kematian mulai terjadi pada hari kedua hingga hari keempat. Virulensi 
bakteri bertambah pada perlakuan dengan kepadatan bakteri lebih tinggi, dengan tandatanda perlukaan yang lebih meluas hingga terjadinya ulcer pada bagian perut dekat sirip ekor. Bagian tersebut merupakan lokasi tempat infeksi buatan (penyuntikan).

Hemoragik yang terjadi pada pangkal sirip punggung, pangkal sirip ekor, dan operkulum, disebabkan oleh toksin hemolisin dengan target memecah sel-sel darah merah, sehingga sel keluar dari pembuluh darah, menimbulkan warna kemerahan pada permukaan kulit (Huys et al., 2002). Terjadinya ulcer disebabkan oleh tingginya kepadatan bakteri pada lokasi tersebut, sehingga volume dan intensitas toksin yang dikeluarkan pada proses infeksi juga lebih tinggi pada bagian tersebut, sementara sebagian lainnya masuk ke dalam tubuh mengikuti aliran darah (Mims, 1987; Robert, 1993).

Daya kerja toksin pada bakteri berkaitan dengan sel reseptor spesifik. Adanya interaksi antara sel reseptor dalam tubuh dengan hemolisin, menimbulkan efek perlukaan pada tubuh. Hal tersebut didukung oleh Virella (1997), bahwa toksin ekstraselular memiliki dua wilayah penentu virulensi yaitu daerah perlekatan yang merupakan daerah tempat toksin melekat pada sel reseptor spesifik dan daerah aktif sebagai penyebab utama infeksi pada sel.

Menurut Chopra et al. (2000); Figueras et al. (2007), A. hydrophila merupakan bakteri akuatik bersifat patogen pada ikan-ikan khususnya ikan air tawar. Selain menginfeksi ikan, bakteri tersebut dapat menyebabkan penyakit pada pencernaan manusia yang bersifat akut terutama pada anak-anak. Setiap strain bakteri Aeromonas yang berbeda memproduksi sejumlah enzim yang berbeda pula. Selain enzim, A. hydrophila juga menghasilkan toksin seperti hemolisin, sitotoksin, dan enterotoksin. Virulensi A. hydrophila melibatkan banyak faktor virulensi dan sangat kompleks. Hemolisin dan enzim bekerja sama dalam membuka jaringan permukaan kulit dan sisik ikan.

Proses invasi bakteri patogen ke dalam tubuh diawali dengan melekatnya bakteri pada permukaan kulit, dengan memanfaatkan pili, flagela dan kait untuk bergerak, dan melekat kuat pada lapisan terluar tubuh ikan yaitu sisik yang dilindungi oleh zat kitin. Selama proses invasi tersebut $A$. hydrophila memproduksi enzim kitinase yang juga berfungsi mendegradasi lapisan kitin sehingga mudah ditembus oleh bakteri. Selain memanfaatkan kitinase $A$. hydrophila juga mengeluarkan enzim lainnya seperti lesitinase dalam upaya masuk ke dalam aliran darah (Wijaya, 2002; Nasran et al., 2003).

Enzim kitinase dan lesitinase memiliki peran penting dalam proses infeksi, seperti disampaikan oleh Harini \& Septaningrum (2006), bahwa proses degradasi lapisan kitin adalah reaksi hidrolisis oleh katalisator kitinase dalam memecah dan pemutusan ikatan $\beta$-1-4glikosidik pada kitin yang melapisi bagian epidermis tubuh ikan. Hasil hidrolisis enzim berupa $\mathrm{N}$-asetil-D-glukosamin yang merupakan oligomer pendek, dapat dimanfaatkan oleh bakteri sebagai sumber karbon, sehingga bakteri dengan mudah dapat menembus lapisan kitin.

Lesitinase menurut Raven \& Johnson (1986); Del Bene \& Schmidt (1997) merupakan enzim ekstraselular yang terdapat pada bakteri patogen dan bekerja menghidrolisis fosfolipid sebagai penyusun membran plasma sel, menjadi fosfokolin dan digliserida, sehingga dapat dimanfaatkan sebagai nutrisi oleh bakteri.

Bakteri bergerak dengan sangat cepat di dalam pembuluh darah, dan dengan mudah mencapai organ-organ penting dari ikan seperti pada sinusoid hati dan ginjal. Lokasi tersebut akan dimanfaatkan oleh bakteri sebagai media tempat hidup dan memperbanyak diri, serta menggunakan nutrisi yang ada di sekitarnya untuk proses metabolisme (Bevelender \& Ramaley, 1979).

Masuknya bakteri dalam tubuh mengaktifkan respons imun dengan memproduksi polimorfonuklear leukosit, seperti melanomakrofag, monosit, dan neutrofil yang berperan sebagai phagocytic sel. Kehadiran leukosit tersebut menyebabkan bakteri mengeluarkan toksin hemolisin yang mengakibatkan terjadinya ulcer dan hemoragik pada permukaan tubuh ikan nila. Hemoragik dan nekrosis juga terjadi pada hati, limpa, dan ginjal yang terinfeksi bakteri $10^{7} \mathrm{cfu} / \mathrm{mL}$ diikuti oleh kematian seluruh sel atau jaringan (Robert, 1993; Post, 1987). Pada saat bersamaan lisosom merupakan organel penghasil enzim hidrolitik di dalam sel hati limpa dan ginjal, melakukan tugasnya dalam melisiskan dinding sel bakteri. Sel-sel bakteri maupun neutrofil yang mati difagositosis oleh makrofag untuk dihidrolisis (Geneser, 1994). 


\section{KESIMPULAN}

Lethal Concentration (LC) ${ }_{50}$ bakteri Aeromonas hydrophila adalah 4,9 $910^{6}$ $\mathrm{cfu} / \mathrm{mL}$. A. hydrophila bersifat patogen, virulen dan menyebabkan kematian $50 \%$ populasi ikan nila pada kepadatan bakteri minimum $10^{6} \mathrm{cfu} / \mathrm{mL}$. Infeksi yang ditimbulkan bersifat akut dengan tanda klinis warna kulit menjadi lebih gelap, hemoragik pada kulit, hemoragik lokal pada pangkal sirip ekor, sirip punggung, dan operkulum, pembengkakan organ hati dan limpa serta pendarahan pada organ pencernaan.

\section{DAFTAR ACUAN}

Buckley, J.T. \& Howard, S.P. 1999. The cytotoxin entherotoxin Aeromonas hydrophila is aerolysin. Infection and Imunnunity, 67(1): 466-467.

Bevelander, G. \& Ramaley, J.A. 1979. Dasardasar histologi, Terj. dari Essential of histology oleh Gunarso, W. $8^{\text {th }}$ ed. Tobing, M.H. \& Sitohang, M.J. (Eds.).1979. Gelora Aksara Pratama, Jakarta, iii $+460 \mathrm{hlm}$.

Cipriano, R.C. 2001. Aeromonas hydrophila and motil Aeromonad septicemia of fish. Fish diseases leaflet 68. United States Department of the Interior fish and wild life service division of fisheries research Washington DC, 25 pp.

Chopra, A.K., Xu, X.I., Ribardo, D., Gonzales, M., Kuhl, K., Peterson, J.W., \& Huston, C.W. 2000. The cytotoxic enterotoxin of Aeromonas hydrophila induces proinflamantory cytokine production and activates arachidonic acid metabolisme in machrophages. Infection and Immunity, 68(5): 2,8082,818

Del Bene,V. \& Schmidt, M.G. 1997. Bacterial virulence factors. Dalam: Virella, G. (Ed.). 1997. Microbiology and infectious disease. $3^{\text {rd }}$ Ed. William \& Wilkins, Baltimore, p. 6570.

Del Coral, F., Shotts, E.B., \& Brown, J. 1990. Adherence haemagglutination and cell surface characteristics of motil aeromonads virulent for fish. J. of Fish Diseases. 13: 255268.

Eissa, I.M., Badran, A.F., Moustafa, M., \& Fetaih, H. 1994. Contribution to Motile Aeromonas in some cultured and wild fresh fish. Veterinary Medical J. Giza, 42(1): 62-69.

Filler, G., Ehrich, J.H.H., Strauch, E., \& Beutin, L. 2000. Acute renal failure in an infant asso- ciated with cytotoxic Aeromonas sobria isolated from patient's stool and from aquarium water as suspected source of Infectio. J. of Clinical Microbiology, 38(1): 469-470.

Figureas, M.J., Horneman, A.J., Murcia, A.M., \& Guarro, J. 2007. Controversial data on the association of Aeromonas with diarrhoea in a recent Hongkong study. J. of Medical Microbiology, 56: 996-998.

Genneser, F. 1994. Buku teks histologi. Terj. dari Textbook of histology, oleh Arifin, G., Kartawiguna, E., \& Arkeman, H. 1994. Binarupa Aksara, Jakarta, xiii + $354 \mathrm{hlm}$.

Harini, N. \& Septariningrum, D. 2006. Karakterisasi enzim chitinase hasil isolasi dari kultur murni bakteri Vibrio alginolyticus. Prosiding Seminar Nasional Tahunan III Hasil Penelitian Perikanan Dan Kelautan. Murwantoko, I., Yusuf, Djumanto, Inansetyo, A., \& Priyono, S.B. (Eds.). Universitas Gadjah Mada, Yogyakarta, hlm. 557565.

Huys, G., Kampfer, P., Albert, M.J., Kuhn, I., Denys, R., \& Swings, J. 2002. Aeromonas hydrophila subsp, dhakensis subps. nov., isolated from children with diarrhoea in Bangladesh, and extended description of Aeromonas hyrdophila subsp. hydrophila (Chester 1901) Stanier 1943 (Approved list 1980). International J. of Systematic and Evolutionary Microbiology, 52: 705-712.

Hubbert, J.J. 1980. Bioassay. Departement of Mathematics and Statistic University of Guelph, Kendal/Hunt Publishing company, USA, iii + 180 pp.

Jawetz, E., Melnick, J.L., Adelberg, E.A., Brooks, G.F., Butel, J.S., \& Ornston, L.N. 1996. Mikrobiologi Kedokteran. Terj. dari Medical Microbiology. 20 th Eds. Setiawan, I (Ed.). 1996. EGC, Jakarta, xiii + 753 hlm.

Komisi Pestisida Departemen Pertanian. 1983. Pedoman umum pengujian laboratoris toksisitas lethal pestisida pada ikan untuk keperluan pendaftaran, Jakarta, $19 \mathrm{pp}$.

Lallier, R., Mittal, K.R., Leblance, D., Lalonde, G., \& Olivier, G. 1981. Rapid methods for differentiation of virulent and non virulent Aeromonas hydrophila strains. Dalam: Karger, S. (Ed.).1981. Serodiagnostics and vaccines. International Symposium on Fish Biologics. National Fish Health Research Laboratory, Leetown USA, April 26-30, 1981. USA, p. 119-123. 
Maturin, L.J. \& Peeler, J.T. 1998. Aerobic plate count Dalam: $8^{\text {th }}$ Ed. FDA Bacteriological analytical manual. AOAC International, USA, p. 1-10.

Mims, C.A. 1987. The pathogenesis of infectious disease. $3^{\text {rd }}$ Ed. Department of Microbiology Guys Hospital Medical School. Academic Press, London, $x i+342$ pp.

Moat, A.G., Foster, J.W., \& Spector, M.P. 2002. Microbial physiology. $4^{\text {th }}$ Ed. Willey \& Liss, Inc, USA, xiv+1 5 pp.

Nasran, S., Ariyani, F., \& Indriyati, N. 2003. Produksi kitinase dan kitin deasetilase dari Vibrio harveyi. J. Pen. Perik. Indonesia, 9(5): 33-38.

Noga, J.E. 2000. Fish disease diagnosis and treatment. Iowa State Press. USA. 366 p.

Popma, T. \& Masser, M. 1999. Tilapia live history and biology. Southern Regional aquaculture. United States Department of agriculture. 283: $4 \mathrm{hlm}$.

Post, G. 1987. Textbook of fish health. T.F.H Publication, Inc. USA, iv+287 pp.

Raven, P.H. \& Johnson, G.B. 1986. The chemical building blocks of life. Dalam: Biologi. Times mirror, St.Louis, p. 55-79.

Roberts, R.J. 1993. Motil Aeromonad Septicemia. Dalam: Inglish,V., R.J. Roberts \& N.R. Bromage (Eds.).1993. Bacterial diseases of fish. Institut of Aquaculture. Blackwell Science Ltd, USA, p. 143-156.
Santos, J.A., Gonzalez, C.J., Otero, A., \& Lopez, M.L.G. 1999. Hemolytic activity and sidephore production in different Aeromonas species isolated fro fish. American society for microbiology-Applied and environmental microbiology, 65(12): 5,612-5,614.

Sudjana, 1988. Diasin dan analisis eksperimen. Transito, Bandung, $283 \mathrm{hlm}$.

Supriyadi, H. 1990. Characterization and virulence studies of Motile Aeromonads isolated from Clarias batrachus and $C$. gariepinus and their immunization potential. Thesis The Degree of Master of Science. Universiti Pertanian Malaysia, xvii +1 12 pp.

Swann, L.D. \& White, M.R. 1991. Diagnosis and treatment of Aeromonas hydrophila infection of fish. Aquaculture extentions, Sea Grant, 2 pp.

Virella, G. 1997. Microbiology and infectious disease. $3^{\text {rd }}$ Ed. William \& Wilkins, Baltimore, p. 65-70.

Wijaya, S. 2002. Isolasi kitinase dari Scleroderma columnare dan Trichoderma harzianum. J. Ilmu Dasar Biologi, 3(1): 30-35.

Yuasa, K.N., Panigoro, M.B., \& Kholidin. 2003. Panduan diagnosa penyakit ikan: Teknik diagnosa penyakit ikan budidaya air tawar di Indonesia. Balai budidaya air tawar Jambi \& Jakarta. International Cooperation agency: iv+75 hlm. 